\title{
PEMETAAN DAN ALTERNATIF PEMANFAATAN LIMBAH CANGKANG RAJUNGAN DI INDONESIA
}

\author{
Kiki Puspita Amaliaa ${ }^{1,2 \star}$, Meti Ekayani ${ }^{2,3}$, Nurjanah ${ }^{4}$ \\ ${ }^{1}$ Badan Karantina Ikan Pengendalian Mutu dan Keamanan Hasil Perikanan, KKP \\ ${ }^{2}$ Departemen Multidisiplin Pengelolaan Sumberdaya Alam dan Lingkungan, IPB University \\ ${ }^{3}$ Departemen Ekonomi Sumberdaya dan Lingkungan, IPB University \\ ${ }^{4}$ Departemen Teknologi Hasil Perairan, IPB University
}

Diterima: 31 Agustus 2021/Disetujui: 26 Oktober 2021

^Korespondensi: kikipuspita@apps.ipb.ac.id

Cara sitasi: Amalia KP, Ekayani M, Nurjanah. 2021. Pemetaan dan alternatif pemanfaatan limbah cangkang rajungan di Indonesia. Jurnal Pengolahan Hasil Perikanan Indonesia. 24(3):310-318.

\begin{abstract}
Abstrak
Pasteurized crab meat merupakan salah satu ekspor terbesar komoditas hasil perikanan di Indonesia. Unit pengolahan ikan (UPI) menerima bahan baku berupa daging rajungan dari miniplant, hal ini menyisakan limbah rajungan yang cukup besar karena sekitar 50-60\% bagian tubuh rajungan adalah cangkang. Penelitian ini bertujuan memetakan rantai pasok terkait pemanfaatan limbah rajungan, termasuk menghitung potensi limbah, nilai ekonomi dan identifikasi alternatif pemanfaatan limbah rajungan. Metode yang dilakukan dengan deskripsi kualitatif, benefit transfer, dan analisis pendapatan. Data hasil penelitian memetakan rantai pasok terkait pemanfaatan limbah rajungan di delapan provinsi berdasarkan pada 37 UPI yang mengolah pasteurized crab meat dan 148 miniplant di sembilan provinsi pemasok bahan baku. Berdasarkan pilihan utama alternatif pemanfaatan oleh responden, jumlah cangkang yang tersedia di setiap provinsi dan nilai ekonomi yang tinggi dari kitosan maka limbah cangkang sangat potensial jika dimanfaatkan sebagai sumber bahan baku kitin dan kitosan.
\end{abstract}

Kata kunci: benefit transfer, kitin, kitosan, pasteurized crab meat

\section{Mapping and Alternative Utilization of Shell Crab Waste in Indonesia}

\begin{abstract}
Pasteurized crab meat is one of the largest fishery export commodities in Indonesia. Fish Processing Unit (FPU) receives raw materials in the form of whole crab from the miniplant, thus leaving a fairly large crab waste because about $50-60 \%$ of the crab is the shell. Previous research has informed that crab waste has potential utilization and it can increase the economic value of the crab waste. This study aims to map the supply chain related to the use of crab waste, including calculate waste potential, economic value and identify alternative uses of crab waste. The method used is a qualitative descriptive, benefit transfer, and income analysis. The result of this study represent supply chain mapping of crab waste utilization in 8 provinces based on $37 \mathrm{FPU}$ and 148 miniplant on 9 provinces that supply raw materials. Based on the main choice of alternative utilization by respondents, the number of shells available in each province and the high economic value of chitosan, shell waste has great potential used as chitosan.
\end{abstract}

Keyword: chitosan, crab, utilization, waste 


\section{PENDAHULUAN}

Indonesia merupakan pengekspor pasteurized crab meat nomor empat terbesar di dunia setelah Rusia, Kanada dan China dengan tujuan utama ekspor adalah Amerika Serikat. Berdasarkan data, potensi rajungan di sebelas wilayah pengelolaan perikanan (WPP) sebesar 60.489 ton dan volume ekspor pasteurized crab meat ini cenderung naik pertahunnya. Persentase kenaikan volume ekspor tahun 2019 ke tahun 2020 naik sebesar 13,25\% berdasarkan data Kementerian Kelautan dan Perikanan (KKP 2020). Unit pengolahan ikan (UPI) memerlukan peningkatan bahan baku berupa daging rajungan dalam pengolahan pasteurized crab meat, hal ini berpotensi meningkatkan limbah cangkang yang dihasilkan oleh miniplant sebagai pemasok bahan baku. Aktivitas industri yang hanya mengambil daging rajungan ini menghasilkan limbah cangkang yang banyak. Suwandi et al. (2019) menyatakan proporsi bagian tubuh rajungan setelah pengupasan adalah cangkang $52,59 \%$, daging $35,68 \%$ dan jeroan $11,73 \%$. Jacoeb et al. (2012) melaporkan bahwa rajungan segar memiliki rendemen yang lebih tinggi, rajungan kukus mengalami penurunan rendemen sebesar 14,99\%. Komposisi proksimat rajungan segar dan kukus berturutturut sebagai berikut: kadar air 75,43\%; abu $6,02 \%$; protein $66,63 \%$; lemak $0,75 \%$; $26,62 \%$; protein larut air (bk) 25,32\%; protein larut garam (bk) $30,77 \%$. Adanya perbedaan proporsi tubuh ini dipengaruhi oleh ukuran, berat, jenis, dan tingkat pertumbuhan.

Limbah cangkang yang dimanfaatkan belum optimal dan sebagian besar dibuang begitu saja ke lingkungan sehingga dapat menimbulkan permasalahan lingkungan antara lain pencemaran bau, dapat menularkan berbagai penyakit, dan mengganggu kenyamanan masyarakat (Supratman et al. 2016). Limbah cangkang memiliki potensi pemanfaatan yang besar, sejalan dengan penelitian terdahulu bahwa limbah cangkang masih dapat dimanfaatkan antara lain sebagai bahan pencampur/suplemen pakan, pupuk, kitin, kitosan, produk pangan dan lainnya (Azizi et al. 2020; Faruqi et al. 2020). Pemanfaatan limbah cangkang rajungan ini dapat memberikan nilai tambah bagi pengelola khususnya miniplant, sehingga sesuai dengan Sustainable Development Goals (SDGs) nomor 12 tentang konsumen dan produksi yang bertanggungjawab, sejalan juga dengan konsep polluter pays principle, yaitu pihak penghasil limbah harus bertanggung jawab terhadap limbah yang dihasilkannya (Noordwijk et al. 2008).

Tujuan penelitian adalah memetakan rantai pasok terkait jumlah dan pemanfaatan limbah rajungan, termasuk menghitung potensi limbah, kapasitas produksi, nilai ekonomi dan identifikasi alternatif pemanfaatan limbah rajungan.

\section{BAHAN DAN METODE Bahan dan Alat}

Penelitian ini menggunakan bahan berupa aplikasi HACCP Online System (HONEST) KKP serta perangkat lunak Microsoft Excel 2010, sedangkan alat yang digunakan berupa kuesioner dengan Google Form yang disebarkan melalui media komunikasi (telepon, zoom dan whatsapp) dan laptop.

\section{Metode}

Data yang digunakan berupa data primer yang diperoleh dari kuesioner dan wawancara (google form, whatsapp, telepon) serta data sekunder berupa nama unit pengolahan ikan (UPI) yang diperoleh dari data HONEST KKP, nama miniplant dari data monitoring KKP, data pemanfaatan limbah cangkang dari jurnal ilmiah dan literatur terkait. Pelaksanaan pengambilan data dilakukan pada bulan Januari-Juni 2021. Jenis informasi/data yang diperlukan, sumber, metode analisis dan metode pengambilan contoh disajikan pada Table 1.

Penentuan responden menggunakan rumus Slovin (Sangaji et al. 2010):

$\mathrm{n}=\frac{\mathrm{N}}{(1+\mathrm{Ne} 2)}$

Keterangan:

$\mathrm{n}=$ Jumlah responden

$\mathrm{N}=$ Jumlah Populasi

$\mathrm{e}=$ Eror atau galat (10\%)

Benefit transfer digunakan untuk mengukur nilai berdasarkan studi lain yang pernah dilakukan di tempat yang 
Table 1 Analysis and sampling method

\begin{tabular}{|c|c|c|c|c|c|}
\hline No & Purpose & Required Data & Data Source & $\begin{array}{l}\text { Analysis } \\
\text { Method }\end{array}$ & $\begin{array}{l}\text { Sampling } \\
\text { Method }\end{array}$ \\
\hline \multirow[t]{6}{*}{1} & \multirow{6}{*}{$\begin{array}{l}\text { Availability } \\
\text { of supply } \\
\text { chain related } \\
\text { to utilization } \\
\text { crab waste in } \\
\text { Indonesia }\end{array}$} & Number of FPU/region & MMAF & $\begin{array}{l}\text { Qualitative } \\
\text { description }\end{array}$ & Census \\
\hline & & FPU Production Capacity & FPU & $\begin{array}{l}\text { Benefit } \\
\text { transfer }\end{array}$ & \\
\hline & & Number of miniplant & Miniplant & & \\
\hline & & $\begin{array}{l}\text { Number of shell waste/ } \\
\text { region }\end{array}$ & & & \\
\hline & & $\begin{array}{l}\text { Percent handling shell } \\
\text { waste/region }\end{array}$ & & & \\
\hline & & $\begin{array}{l}\text { Percent selling purpose/ } \\
\text { region }\end{array}$ & & & \\
\hline \multirow[t]{2}{*}{2} & $\begin{array}{l}\text { Availability } \\
\text { of potential }\end{array}$ & $\begin{array}{l}\text { Utilization of shell waste } \\
\text { based on literature }\end{array}$ & Literature & $\begin{array}{l}\text { Qualitative } \\
\text { description }\end{array}$ & $\begin{array}{l}\text { Purposive } \\
\text { sampling }\end{array}$ \\
\hline & $\begin{array}{l}\text { utilization of } \\
\text { crab waste }\end{array}$ & $\begin{array}{l}\text { Percent of respondent } \\
\text { choices regarding } \\
\text { utilization of shell waste }\end{array}$ & FPU & $\begin{array}{l}\text { Income } \\
\text { analysis }\end{array}$ & \\
\hline
\end{tabular}

Chitosan information Miniplant

Calculation of value added

of shell waste as chitosan

\section{sama maupun berbeda (Fauzi 2015). \\ Jumlah cangkang ini dihitung dengan cara mengurangi jumlah total rajungan yang diterima dengan jumlah daging dan jeroan yang dihasilkan, hal ini menggunakan metode benefit transfer dari penelitian Suwandi et al. \\ $\mathrm{TR}=$ Total penerimaan \\ $\mathrm{TC}=$ Total biaya \\ $\mathrm{Q}=$ Jumlah Produk \\ $\mathrm{P} \quad=$ Harga Produk \\ TFC $=$ Total biaya tetap \\ $\mathrm{TVC}=$ Total biaya variabel} (2019). Nilai tambah didapatkan dari analisis pendapatan yang bertujuan untuk mengetahui besar keuntungan yang diperoleh dari usaha yang dilakukan (Elza et al. 2020; Soekartawi 1995).

$\pi=\mathrm{TR}-\mathrm{TC}$

$\mathrm{TR}=\mathrm{Q} \times \mathrm{P}$

$\mathrm{TC}=\mathrm{TFC}+\mathrm{TVC}$

Keterangan:

$\pi=$ keuntungan (nilai tambah)
Analisis data dilakukan secara deskripsi kualitatif dengan perhitungan menggunakan Microsoft Office (Excel) versi 2010 untuk menghitung jumlah cangkang, persentase penanganan, serta persentase penjualan limbah cangkang di tiap wilayah. 


\section{HASIL DAN PEMBAHASAN Rantai Pasok Terkait Pemanfaatan Limbah Rajungan di Indonesia}

Rantai pasok untuk industri pasteurized crab meat dimulai dari nelayan, bakul, miniplant, UPI sampai importir. Pengambilan sampel UPI berdasarkan data UPI yang aktif berproduksi di data KKP, sedangkan data miniplant dilakukan sesuai data yang diberikan oleh UPI dan telah diverifikasi melalui data di KKP. Penelitian ini dibatasi dari miniplant karena miniplant yang melakukan pengupasan rajungan sebelum dipasok ke UPI sebagai bahan baku. Rantai pasok terkait rajungan dan limbah rajungan selama ini disajikan pada Figure 1.

Figure 1 menunjukkan bahwa rantai pasok limbah rajungan selama ini berhenti di miniplant sebagai pengupas rajungan. Hasil dari pengupasan tersebut adalah limbah cangkang yang oleh miniplant ditangani dengan membuangnya ke lingkungan serta ada yang menjual pada pihak pembeli limbah cangkang.

UPI pengolah pasteurized crab meat di Indonesia menurut data HONEST KKP adalah sebanyak 37 unit yang tersebar di delapan provinsi. Dari data UPI tersebut diperoleh 148 miniplant yang tersebar di 9 provinsi. Data jumlah rajungan diperoleh dari masingmasing miniplant pemasok bahan baku ke 37 UPI yang terdata. Diperoleh 148 miniplant dengan jumlah cangkang berkisar antara 25$1.300 \mathrm{~kg}$ per-hari. Jumlah UPI, miniplant dan limbah cangkang disajikan pada Figure 2.

Berdasarkan Figure 2 jumlah UPI dan miniplant terbanyak di Provinsi Jawa Timur sebanyak 9 UPI dan 37 miniplant. Jumlah cangkang terbesar berada di Jawa Tengah sebesar 11,15 ton/hari, hal ini karena miniplant di Jawa Tengah mengolah rajungan dengan jumlah yang lebih banyak yaitu 18,25 ton/hari dibandingkan Jawa Timur yaitu 15,87 ton/hari. Sumber data berasal dari informasi yang diperoleh dari UPI dan miniplant terkait jumlah cangkang rajungan, kemudian dijumlahkan tiap wilayah. Bangka Belitung tidak memiliki UPI namun memiliki tiga miniplant rajungan yang memasok bahan baku ke UPI di Jawa Timur dan memiliki potensi limbah cangkang sebesar 1 ton per hari. Data jumlah limbah cangkang rajungan yang dihasilkan disajikan pada Figure 3.

Figure 3 menunjukkan jumlah limbah cangkang dari 148 miniplant sebesar 43,03 ton perhari, data ini diperoleh menggunakan metode benefit transfer jumlah limbah cangkang (Suwandi et al. 2019). Perhitungan dilakukan di setiap miniplant dengan mengurangi jumlah total rajungan yang diterima dengan jumlah daging dan jeroan yang dihasilkan. Persentase rata-rata limbah cangkang didapatkan sebesar 63,65\% dari total berat rajungan. Hal ini sesuai

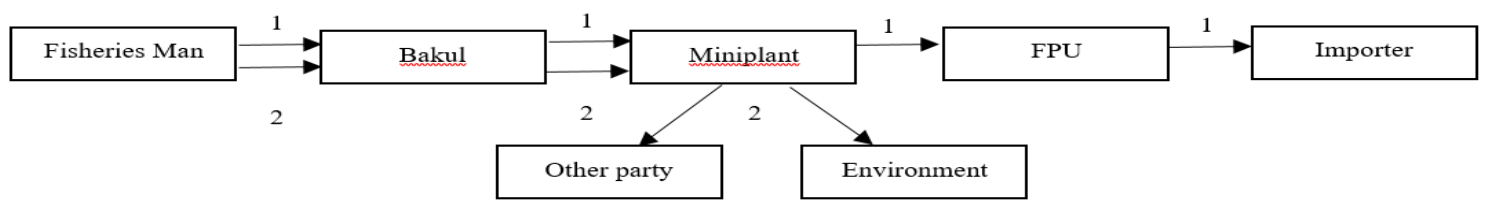

Figure 1 Supply chain of pasteurized crab meat (1) and crab waste (2)

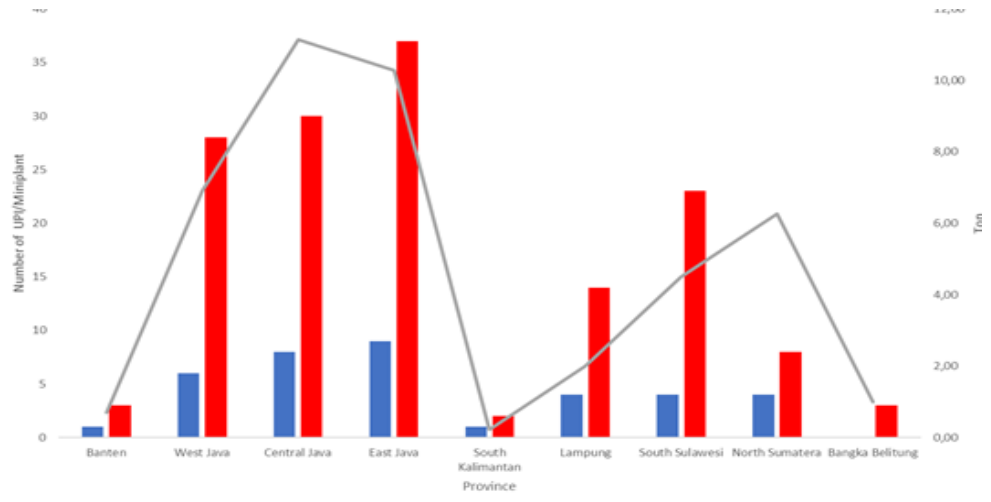

Figure 2 Number of fpu, miniplant and shell waste 


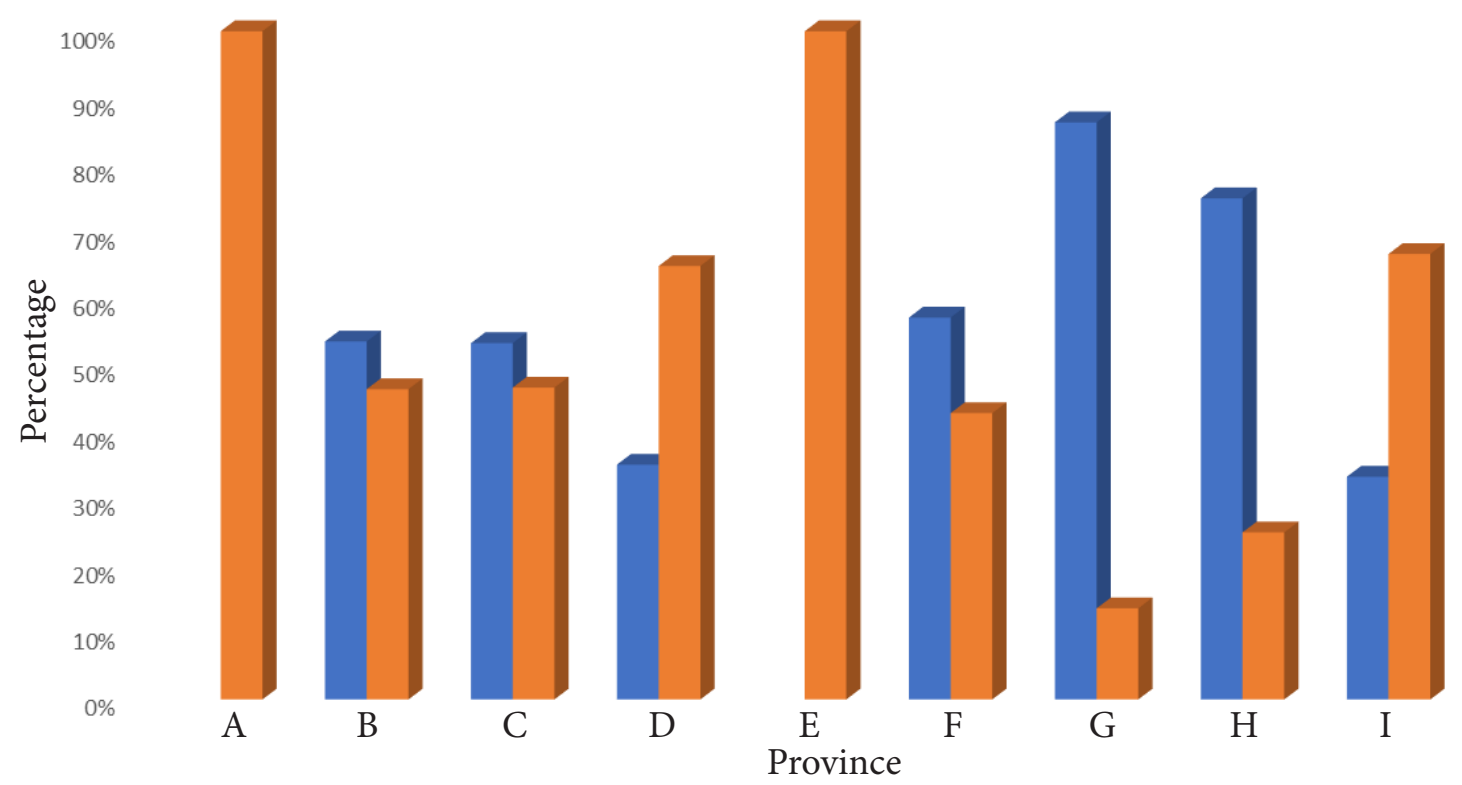

Figure 3 Shell crab waste distribution per province; $\square$ disposed to environment; $\square$ sold to other parties; (A) Banten; (B) West Java; (C) Central Java; (D) East Java; (E) South Kalimantan; (F) Lampung; (G) South Sulawesi; (H) North Sumatra; (I) Bangka Belitung.

dengan penelitian Suwandi et al. (2019) dan Rochima (2014) yang menyatakan bahwa limbah cangkang sekitar $40-60 \%$ dari total berat rajungan. Dari sensus yang dilakukan, penanganan limbah cangkang di miniplant hanya berupa penjualan dan pembuangan cangkang, belum ada miniplant yang memanfaatkan dengan mengolah limbah cangkang tersebut. Data penanganan di miniplant disajikan pada Figure 3.

Figure 3 menunjukkan bahwa mayoritas miniplant melakukan kedua kegiatan, yaitu menjual dan membuang limbah cangkang, kecuali miniplant di Banten dan Kalimantan Selatan yang seluruhnya menjual cangkang tersebut. Wilayah yang membuang cangkang lebih banyak dibanding menjual cangkang antara lain Jawa Barat, Jawa Tengah, Lampung, Sulawesi Selatan, dan Sumatra Utara. Sedangkan wilayah yang menjual cangkang lebih banyak dibanding membuang cangkang adalah Jawa Timur dan Bangka Belitung.

Miniplant yang membuang limbah cangkang diberikan pertanyaan terkait peruntukan penjualan limbah cangkang tersebut. Mayoritas miniplant sebanyak 65\% tidak mengetahui tujuan pembelian limbah cangkang tersebut, sedangkan 35\% miniplant memberikan informasi peruntukan limbah cangkang terjual yaitu digunakan sebagai pakan ternak. Persentase peruntukan limbah terjual di masing-masing wilayah disajikan pada Figure 4.

Figure 4 menjelaskan bahwa peruntukan limbah cangkang sebagai pakan paling tinggi di Kalimantan Selatan, kemudian diikuti oleh Jawa Barat, Jawa Tengah, Lampung, Bangka Belitung dan Jawa Timur. Sedangkan di Banten, Sulawesi Selatan dan Sumatra Utara seluruh miniplant tidak mengetahui peruntukkan limbah cangkang terjual.

\section{Potensi Limbah, Nilai Ekonomi dan Alternatif Pemanfaatan Limbah Rajungan}

Pemanfaatan limbah cangkang rajungan sudah cukup banyak menjadi subjek penelitian, sehingga dalam penelitian ini dilakukan studi literatur dan diperoleh informasi bahwa berdasarkan jurnal pemanfaatan limbah cangkang rajungan selama tahun 2007-2020 diperoleh 4 kelompok besar pemanfaatan limbah cangkang, yaitu sebagai bahan baku industri (kitosan), pakan hewan, produk pangan, dan pupuk (Balkhande et al. 2020; Husni et al. 2020; Kurniawan et al. 2017; Kurnia et al. 2016). 


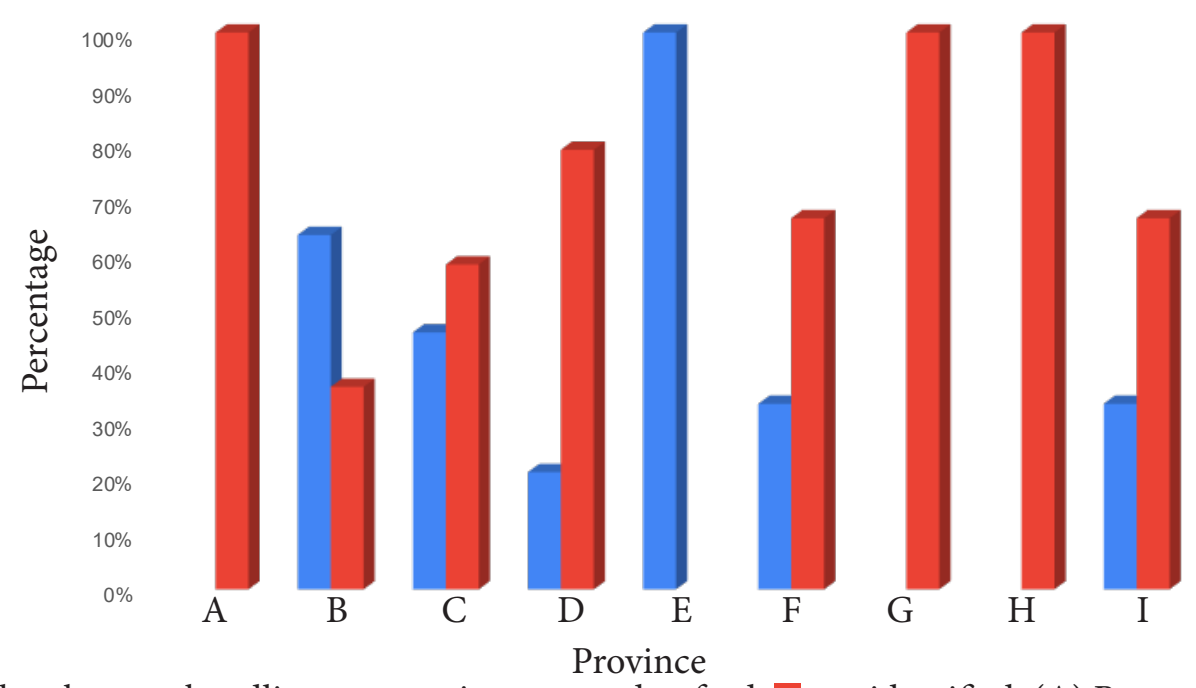

Figure 4 Shell crab waste handling per province; $\square$ used as feed; $\square$ not identified; (A) Banten

(B) West Java; (C) Central Java; (D) East Java; (E) South Kalimantan; (F) Lampung; (G) South Sulawesi; (H) North Sumatra; (I) Bangka Belitung.

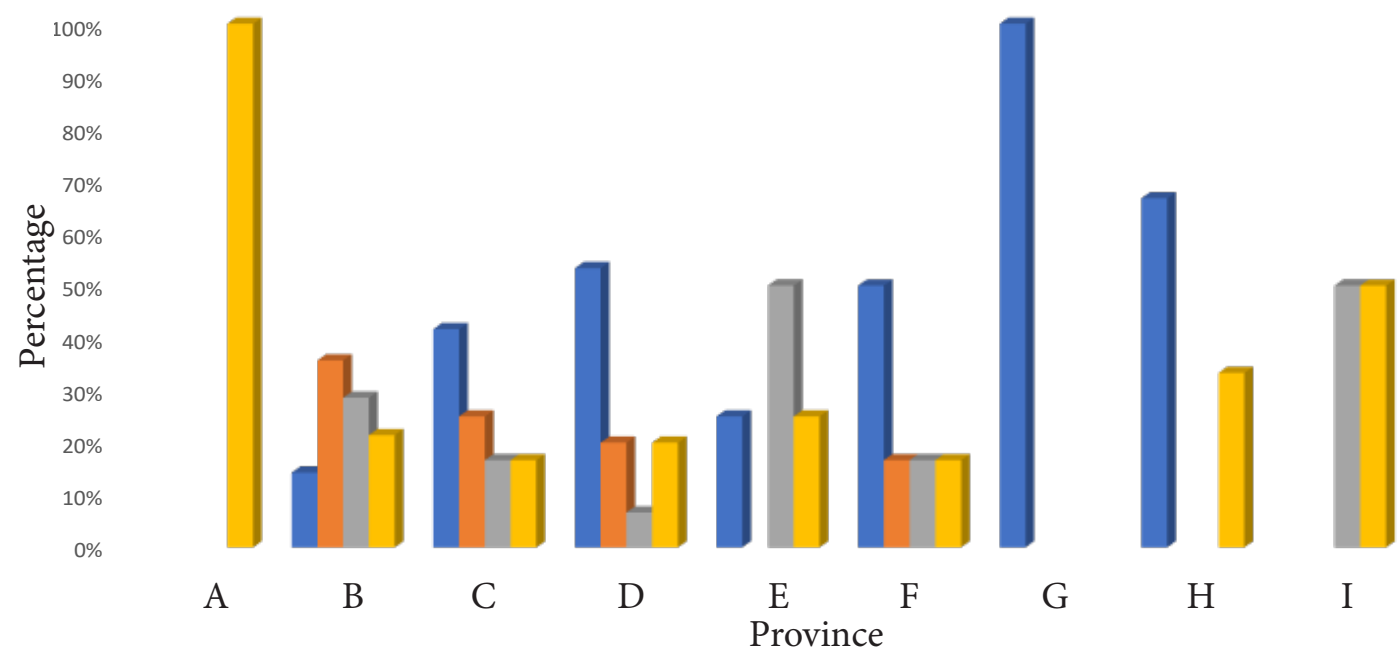

Figure 5 Respondent choices regarding utilization of shell waste per province; 1 chitosan; feed; fisheries product; fertilizer; (A) Banten; (B) West Java; (C) Central Java; (D) East Java; (E) South Kalimantan; (F) Lampung; (G) South Sulawesi; (H) North Sumatra; (I) Bangka Belitung.

Mayoritas responden di beberapa wilayah memilih pemanfaatan limbah cangkang sebagai bahan baku industri (kitosan), hal ini sejalan dengan isu terkini pemanfaatan limbah cangkang sebagai kitosan yang dilkukan oleh Azizi et al. (2020), dan Husni et al. (2020). Data pilihan responden dalam memanfaatkan limbah cangkang rajungan disajikan pada Figure 5.

Figure 5 menunjukkan lima provinsi yang memilih kitosan sebagai pilihan pertama pemanfaatan limbah cangkang, yaitu Jawa Tengah, Jawa Timur, Lampung, Sulawesi Selatan dan Sumatra Utara. Banten seluruhnya memilih pupuk sebagai pilihan pemanfaatan, Jawa Barat memilih pakan sebagai pilihan pertama, Kalimantan Selatan memilih produk pangan sebagai pilihan pertama, sedangkan Bangka Belitung memilih produk pangan dan pupuk sebagai pilihan pertama pemanfaatan limbah cangkang. Kitosan adalah senyawa turunan dari kitin yang banyak ditemukan pada cangkang hewan laut seperti udang, kepiting dan rajungan. 
Kitosan bermanfaat bagi kehidupan manusia, sebagai bahan pengawet dan antijamur pada bidang pangan, antibakteri, adsorben logam berat dan lainnya. Hasil peneltian Rohima (2007) menunjukkan bahwa potensi cangkang rajungan sebagai bahan baku kitosan adalah sebagai berikut: rendemen $69,5 \%$, kelarutan $79,39 \%$, derajat deasetilasi $70,7 \%$, viskositas intrinsik $6,93 \mathrm{~mL} / \mathrm{g}$, berat molekul $8,75 \times 10^{3}$. Untuk meningkatkan pemanfaatan kitosan juga telah dilakukan penelitian tentang depolimerisasi kitosan menggunakan sinar ultraviolet dan katalis asam klorida yang menghasilkan rendemen $70,07 \pm 14,00 \%$, kelarutan 99,80 $\pm 0,17 \%$, derajat putih $99,99 \pm 0,00 \%$, viskositas $49,78 \pm 0,31 \mathrm{cP}$, bobot molekul $169,46 \pm 0,30 \mathrm{kDa}$, dan zeta potensial 7 3,03 $\pm 1,92 \mathrm{mV}$ (Nuryadin et al. 2020).

Pemanfaatan yang luas ini membutuhkan kitosan dalam jumlah banyak, dan kebutuhan bahan baku dari cangkang rajungan akan sangat mendukung produksi kitosan. Negara produsen kitin kitosan terbesar saat ini adalah Jepang dan Amerika, di pasar internasional harga kitin mencapai US\$ 5-10/kg, sedangkan kitosan mencapai US\$15-40/kg. Perhitungan nilai tambah limbah cangkang menggunakan analisis pendapatan (Elza et al. 2020; Soekartawi 1995). Perhitungan nilai tambah kitosan disajikan pada Table 2.

Berdasarkan data di Table 2 nilai tambah cangkang jika dijual begitu saja sebagai cangkang (bahan baku pakan) didapatkan nilai tambah sebesar Rp2.000/kg, sedangkan jika dimanfaatkan sebagai kitosan oleh pihak lain, maka didapatkan nilai tambah sebesar Rp18.000/kg. Jika miniplant sendiri yang memanfaatkan akan diperoleh nilai tambah lebih besar sebesar Rp20.000/kg. Perhitungan ini belum menambahkan biaya tetap seperti biaya mesin, sewa bangunan, listrik. Pemanfaatan limbah cangkang sebagai kitosan yang memiliki nilai tambah yang tinggi dan didukung dengan jumlah cangkang yang tinggi diharapkan mampu menjadi salah satu alternatif peningkatan nilai tambah limbah rajungan. Menurut Supriyantini et al. (2018), kitosan yang berasal dari rajungan dapat digunakan sebagai bahan bioadsorben untuk menurunkan jumlah logam berat timbel $(\mathrm{Pb})$ pada limbah cair, sedangkan menurut Husni et al. (2020) kitosan berperan dalam bidang farmasi antara lain sebagai antibakteria.

Table 2 Chitosan added value

\begin{tabular}{|c|c|c|c|}
\hline Component & Shell & $\begin{array}{l}\text { Chitosan by } \\
\text { other party }\end{array}$ & $\begin{array}{c}\text { Chitosan by } \\
\text { miniplant }\end{array}$ \\
\hline \multicolumn{4}{|l|}{ Input } \\
\hline Numbel of shell waste/Q $(\mathrm{kg})$ & 100 & 100 & 100 \\
\hline Selling price/P (Rp/kg product) & 2,000 & 350,000 & 350,000 \\
\hline Total income /TR (Rp/100kg of shell waste) & 200,000 & $7,000,000$ & $7,000,000$ \\
\hline \multicolumn{4}{|l|}{ Output } \\
\hline Fix cost/FC (Rp/year) & - & - & - \\
\hline Total fix cost/TFC (Rp/year) & - & - & - \\
\hline Variabel cost/VC & - & $5,000,000$ & $5,000,000$ \\
\hline \multicolumn{4}{|l|}{ Production cost ( $\mathrm{Rp} / 100 \mathrm{~kg}$ of shell waste) } \\
\hline Buying cost ( $\mathrm{Rp} / 100 \mathrm{~kg}$ of shell waste) & & 200,000 & 0 \\
\hline Total variabel cost/TVC (Rp) & & $5,200,000$ & $5,000,000$ \\
\hline Total cost/TC (Rp) & & $5,200,000$ & $5,000,000$ \\
\hline Value added of shell waste/100 $\mathrm{kg}(\mathrm{Rp})$ & 200,000 & $1,800,000$ & $2,000,000$ \\
\hline Value added of shell waste/kg (Rp) & 2,000 & 18,000 & 20,000 \\
\hline
\end{tabular}

Note: $1 \mathrm{~kg}$ chitosan is made from $5 \mathrm{~kg}$ of shell waste; Source: CV. X (Chitosan Unit Processing) 


\section{KESIMPULAN}

Rantai pasok rajungan di wilayah Indonesia terdiri dari 148 miniplant yang tersebar di sembilan provinsi dan memasok bahan baku ke-37 UPI di delapan provinsi. Potensi limbah cangkang terbanyak terdapat di Provinsi Jawa Tengah karena selain memiliki banyak miniplant, jumlah rajungan yang diolah pun tinggi. Alternatif pemanfaatan limbah cangkang yang diminati mayoritas responden adalah kitosan karena memiliki nilai tambah yang tinggi.

\section{DAFTAR PUSTAKA}

Azizi A, Fairus S, Mihardja EJ. 2020. Pemanfaatan limbah cangkang rajungan sebagai bahan kitin dan kitosan di purchasing crap unit eretan "atul gemilang" Indramayu. Jurnal Solma. 9(2): 411-419.

Balkhande JV. 2020. Devising of organic fertilizer from fish and crab wastes: waste to best technology. International Journal of Fisheries and Aquatic Studies. 8(2): 0105.

Elza NI, Ekayani M, Ismail A. 2020. Pengelolaan sampah berbasis masayarakat: layakkah secara finansial? (studi kasus: bank sampah rangga mekar). Jurnal Ekonomi Pertanian dan Agribisnis (JEPA). 4(2): 335-342.

Faruqi MU. 2020. Pemanfaatan limbah cangkang rajungan (Portunus pelagicus) sebagai produk pangan di Kabupaten Cirebon. Jurnal Pusat Inovasi Masyarakat. 2 (1): 12-17.

Fauzi. 2015. Valuasi ekonomi dan penilaian kerusakan sumber daya alam dan lingkungan. Bogor (ID): IPB Press.

Husni P, Junaedi, Gozali D. 2020. Potensi kitosan bersumber dari limbah cangkang rajungan (Portunus pelagicus) dalam bidang farmasi. Majalah Farmasetika 5(1): 32-38.

Jacoeb AM, Nurjanah, Lingga LABr. 2021. Karakteristik protein dan asam amino daging rajungan (Portunus pelagicus) akibat pengukusan. Jurnal Pengolahan Hasil Perikanan Indonesia.15(2):156-163.

[KKP] Kementerian Kelautan dan Perikanan. 2020. HACCP Online System. Jakarta (ID):
Kementerian Kelautan dan Perikanan Badan Karantina Ikan dan Pengendalian Mutu.

[KKP] Kementerian Kelautan dan Perikanan. 2020. Limbah Kitin yang Bernilai Tambah. Diunduh pada 10 Agustus 2021. Tersedia pada: https://news.kkp.go.id/index.php/ limbah-kitin-yang-bernilai-tambah

Kurnia A, Muskita WH, Astuti O, Asnani, Harahap W. 2016. Evaluasi penggunaan tepung cangkang rajungan sebagai bahan baku pakan juwana udang windu Penaeus monodon. Jurnal Akuakultur Indonesia. 15(2): 117-123.

Kurniawan, Yunita A, Christianingrum. 2017. Peningkatan produksi pertanian dengan pemanfaatan limbah cangkang rajungan menjadi pupuk organik di Pulau Seliu, Kabupaten Belitung. Jurnal Pengabdian Kepada Masyarakat Universitas Bangka Belitung. 4(2): 54-61.

Noordwijk MV, Leimona B, Jindal R, Villamor GB, Vardhan M, Namirembe S, Catacutan D, Kerr J, Minang PA, Tomich TP. 2008. Payments for environmental services: evolution toward efficient and fair incentives for multifunctional landscapes. Annual Review of Environment and Resources. 37: 389-420.

Nuryadin DFE, Setyaningsih I, Hardiningtyas SD. 2020. Depolimerisasi kitosan menggunakan sinar ultraviolet dan katalis asam klorida. Jurnal Pengolahan Hasil Perikanan Indonesia. 23(3): 412-422.

Rochima E. 2014. Kajian pemanfaatan limbah cangkang rajungan dan aplikasinya untuk bahan minuman kesehatan berbasis kitosan. Jurnal Akuatika. 5(1): 71-82.

Rochima E. 2007. Karakterisasi kitin dan kitosan asal limbah rajungan Cirebon Jawa Barat. Buletin Teknologi Hasil Perikanan. 10(1):9-22

Sari MN, Fransiska Y, Mahmiah. 2020. Dampak virus corona (covid-19) terhadap sektor kelautan dan perikanan : a literature review. Journal of Tropical Marine Research. 2(2): 59-66.

Soekartawi. 1995. Analisis Usahatani. Jakarta (ID): Universitas Indonesia.

Supratman O, Umroh. 2016. Pemberdayaan masyarakat dalam pemanfaatan limbah 
cangkang rajungan sebagai pakan ikan di Desa Tukak, Bangka Selatan. Jurnal Pengabdian Kepada Masyarakat Universitas Bangka Belitung. 3(2): 8-14. Supriyantini E, Yulianto B, Ridlo A, Sedjati S, Nainggolan AC. 2018. Pemanfaatan chitosan dari limbah cangkang rajungan (Portunus pelagicus) sebagai adsorben logam timbal $(\mathrm{Pb})$. Jurnal Kelautan Tropis. 21(1): 23-28.

Suwandi R, Nurjanah, Ula MZ, Pertiwi RM. 2020. Characteristics of chemical compounds of horseshoe crabs Tachypleus gigas in different body proportions. IOP Conference Series: Earth and Environmental Science. 404012029. 